\title{
A Systematic Theory of Tradition
}

\author{
James Alexander \\ Dept. of Political Science, Bilkent University, Ankara \\ jalexand@bilkent.edu.tr
}

\begin{abstract}
We still lack a systematic or complete theory of tradition. By referring to the works of many major figures of the last century - Arendt, Boyer, Eisenstadt, Eliot, Gadamer, Goody, Hobsbawm, Kermode, Leavis, MacIntyre, Oakeshott, Pieper, Pocock, Popper, Prickett, Shils and others - I show that a theory of tradition must include insights taken not only from the study of sociology and anthropology, but also from the study of literature and religion (and, it goes without saying here, the study of philosophy and history). The proliferation of separate academic subjects does not make it any less necessary for us to attempt to say in general what we are talking about when we talk about tradition. In this article I distinguish three elements which are found in traditions. I call these continuity, canon, and core. The argument is that traditions can be distinguished in terms of whether there is a core in addition to canon and continuity, a canon in addition to continuity, or only mere continuity. Together these form a theory of tradition which enables us to see what is necessary to all traditions and also what it is which distinguishes different types of tradition from each other.
\end{abstract}

\section{Keywords}

tradition - theory - anthropology - literature - religion

For G.S. (“Tradition!”). 
We are more conscious of tradition now than we have ever been. The word is very old, and what it stands for even older. In a recent historical study of the term, Prickett tells us that

a record of historical etymology such as the Oxford English Dictionary suggests that at first sight there has actually been remarkably little change in the meaning of the word "tradition" itself from the time when Tertullian and the Church Fathers took the Latin traditio, in its legal meaning of "handing over" or "delivery", and wrote by analogy of the Traditio evangelica - or Catholica. This standard ecclesiastical definition, that "of bequeathing any Doctrine to posterity from age to age" remained more or less unaffected by its translation into English. ${ }^{1}$

This standard definition has been complicated in the last few centuries. "Tradition, as both word and concept, fell ... out of use during the seventeenth and eighteenth centuries, and underwent... a dramatic revival in the nineteenth centuries." ${ }^{2}$ This revival was accompanied by an extension of meaning, so that not only doctrines but rituals and symbols and perhaps even objects could be bequeathed to posterity and called tradition. It is this extension of meaning which lies behind the academic attempt of the last century or so to theorize its meaning. The most famous study in English is probably still the book by the sociologist Edward Shils entitled Tradition. He set up a seminar on this subject in Chicago in the 1950s. "No one went into [tradition]", he commented later. "I decided to go into it". ${ }^{3}$ He soon had a manuscript of two hundred pages but found the subject a difficult one and did not complete his book until the 1980s. It is still the major theoretical work on the subject. ${ }^{4}$

Shils observes, as everyone does, that the word tradition comes from traditio, which is derived from the verb tradere, a combination of trans and dare, meaning to surrender, deliver or hand over. Tradition is not as simple as trade,

1 Stephen Prickett, Modernity and the Reinvention of Tradition: Backing into the Future (Cambridge: Cambridge University Press, 2009), 28.

2 Ibid., 1.

3 Edwards Shils, A Fragment of a Sociological Autobiography: The History of My Pursuit of a Few Ideas, ed. Stephen Grosby (London: Transaction, 2006), 130.

4 Nothing has replaced it. For instance, Sanford Budick's book, The Western Theory of Tradition: Terms and Paradigms of the Cultural Sublime (New Haven: Yale University Press, 200o), still depends on Shils. 
that is, simple exchange: it is a word which for about two thousand years has been particularly associated with the handing over of something in time, by some sort of deliberate act of preservation or repetition or recollection, so that the something is not lost to the past. Traditions enable us to inherit things from our ancestors, bestow them on our successors. Shils understands tradition in terms of tradita (the plural of traditum): things which are handed over. These, he argues, can be objects, or beliefs, or simply the ways things are done. He defines tradition simply as "anything which is transmitted or handed down from past to present". 5 This is by far the most capacious theory of tradition there is.

Tradition [according to Shils] - that which is handed down - includes material objects, beliefs about all sorts of things, images of persons and events, practices and institutions. It includes buildings, monuments, landscapes, sculptures, paintings, books, tools, machines. It includes all that a society of a given time possesses and which already existed when its present possessions came upon it and which is not solely the product of physical processes in the external world or exclusively the result of ecological and physiological necessity. ${ }^{6}$

This is a remarkable definition. It accords with no other definition I have seen. It is not entirely inclusive. Shils says, rightly, that action is not part of tradition - I will say more on this below. But here he appears to be saying that objects are part of tradition. This is careless. For it turns tradition into a matter of accident. Shils concentrates so much on the fact that traditions are bestowed that he forgets that they are also received. Tradition is not capricious or unconscious. It is about the conscious bestowing of a tradition on a successive generation or the conscious assimilation of an older truth or ritual - derived from some antique object which can be read (a text, a monument, a grave) or some supposedly antique act which can be in some sense repeated. We can of course with some irony call rubbish a legacy to posterity, but to call it tradition would be to make a mess of our language. Shils's definition is so capacious that it cannot explain what makes certain traditions matter to us. If tradition were to be anything which exists in the present after being been handed down (or thrown away) by someone in the past, then we would be unable to distinguish the Bible or The Waste Land from waste paper. Prickett

5 Edward Shils, Tradition (Chicago: Chicago University Press, 1981), 12.

6 Ibid., 12. 
comments that Shils was concerned "more with taxonomy than analysis". ${ }^{7}$ But even as taxonomy his book is inadequate.

The present article begins with the assumption that any attempt to propose a theory of tradition cannot ignore the difficulties intrinsic to the subject. The Bible is not The Waste Land; The Waste Land is not poetic recitation of the sort found in African tribal rituals studied by anthropologists; ${ }^{8}$ and none of these is rubbish. A theory of tradition must discriminate between these. In coming up with my own theory of tradition I have therefore turned to other writers besides Shils who wrote about tradition at the time when the fundamentals of its nature were being questioned. In chronological order, the most suggestive writings on tradition since the early twentieth century (and, certainly, the ones I have found most useful in developing and clarifying my theory) are:

- T.S. Eliot, "Tradition and the Individual Talent" (1919),

- Michael Oakeshott, "Rationalism in Politics" (1947),

- Karl Popper, “Towards a Rational Theory of Tradition” (1948),

- F.R. Leavis, The Great Tradition (1948),

- Michael Oakeshott, "Political Education" (1951),

- Josef Pieper, “The Concept of Tradition” (1958),

- Hans Georg Gadamer, Truth and Method (1960),

- Hannah Arendt, Between Past and Future (1961),

- Yves Congar, The Meaning of Tradition (1964),

- J.G.A. Pocock, "Time, Institutions and Action: An Essay on Traditions and their Understanding" (1968)

- Edward Shils, Tradition (1981)

- Eric Hobsbawm, "Inventing Traditions" (1983),

- Alasdair MacIntyre, Three Rival Versions of Moral Enquiry: Encyclopaedia, Genealogy, Tradition (1985),

- Alasdair MacIntyre Whose Justice? Which Rationality? (1988),

- Stephen Clark, "Reason, Value and Tradition" (1989),

- Pascale Boyer, Tradition as Truth and Communication (1990),

- Jack Goody, The Power of the Written Word (2000), and

- Stephen Prickett, Modernity and the Reinvention of Tradition (2009).

With one or two exceptions, these writings are not especially recent ones. This is because it seems to me that most recent scholarship has either taken some

7 Prickett, Modernity, 14.

8 This is a deliberate reference. Goody makes much in his books of the ritual recitations accompanied by percussion, called "bagre", of the LoDagaa people. 
sort of definition for granted in order to write about a particular tradition or assumed that in the postmodern condition everything is so malleable that all definitions and theories of tradition can so easily be countered by rival ones that there is no point asking ourselves what a tradition is. This, I claim, cannot be right. Hence my return to the best writings of the last century. The list of works I cite may seem rather miscellaneous. The authors vary: some are anthropologists, some historians, some literary critics, and some philosophers. Yet I think this very important. Any good theory of tradition must recognize that the subject of tradition cannot be limited to one academic field. ${ }^{9} \mathrm{~A}$ concern with tradition must transcend narrowness. In the last fifty years there have been countless anthropological, historical or literary studies of all sorts of traditions, including scientific traditions. Thomas Kuhn's Structure of Scientific Revolutions (1962) comes to mind. If one searches for "tradition" in a university library catalogue one finds books on the Gothic tradition, the Epic tradition, the Islamic tradition, the Classical tradition, the Byzantine tradition, the Augustinian tradition and so on. But most of these books, as Boyer pointed out, take the concept of tradition wholly for granted. ${ }^{10}$ I do not think we can simply take it for granted. The books I list above are a useful beginning because they do not take it for granted. But none of them has put forward anything like a systematic and structured theory of tradition.

This article is an attempt to consider the rival views of tradition in relation to each other, and to combine them in a complete theory. ${ }^{11}$ This is not a theory of the stipulative sort, of the sort which arguably insists that some $\mathrm{x}$ - like justice or society or whatever - has to be an $\mathrm{x}$ of this rather than of that sort. Such theories tend to be dominant nowadays: but these theories, like Rawls's theory of justice, Beck's theory of risk and Wallerstein's theory of world systems, are what Shaw called "toy theories", that is to say, hypothetical theories - the sort of theory one toys with. ${ }^{12}$ I do not want to pursue an arguable if into an improbable then. Nor I do not want to say that all traditions have to be traditions of this

9 Interestingly, Shils acknowledged a debt to T.S. Eliot. Shils, Tradition, viii. It may also be of interest to note that of his "coevals" the only ones whose ideas were "congenial" to him were Oakeshott and, on "at least on two points (one of which one was tradition), Popper". Shils, A Fragment of a Sociological Autobiography, 153.

10 Pascale Boyer, Tradition as Truth and Communication (Cambridge: Cambridge University Press, 1990), 9 .

11 For an earlier study of some rival interpretations see James Alexander, 'Three Rival Views of Tradition (Arendt, Oakeshott, MacIntyre)',Journal of the Philosophy of History 6 (2012), 20-43.

12 Quoted in James Alexander, Shaw's Controversial Socialism (Gainesville: University Press of Florida, 2009), 13. 
rather than of that sort. Instead of toying with an arguable hypothesis, what I want to do is indicate a structural understanding of the varying characteristics of what we have until now imagined traditions to be. The idea is to include all hypotheses within one theory. To this end, first, I shall consider some fundamental antinomies which make any account of tradition problematic. Then I shall outline three successively further specified elements which may be found in traditions - the continuous, canonical and core elements. As we shall see, it is a condition of all traditions that they have continuity, but not a condition that they have canons or cores: nonetheless, a tradition with a canon is radically different from a tradition without a canon, just as a tradition with a core is radically different from a tradition without a core.

\section{Three Preliminary Antinomies}

Before I begin, I think it is necessary to deal with three difficulties which often arise in any casual discussion and sometimes even in academic discussion about tradition. These take the form of antinomies, and are:

1. the antinomy of "tradition" and "modernity";

2. the antinomy of "tradition" and "rationalism"; and

3. the antinomy of "tradition" and "history".

The antinomy of "tradition" and "modernity" is an intensification of the tension between the claim "This is how we have always done it" and the claim "This is not how we do it now". ${ }^{13}$ In the last few centuries we are in the strange situation of having lost our traditions - so we can speak of ourselves living in "post-traditional societies" - and yet finding traditions everywhere. As Arendt has shown, the tradition we have lost is political, or, rather, political and religious: the ancient sense that there is some harmony between the political order and the natural order.

Tradition preserved the past by handing down from one generation to the next the testimony of the ancestors, who first had witnessed and created the sacred founding and then augmented it by their authority throughout the centuries. As long as this tradition was uninterrupted, authority was inviolate; and to act without authority and tradition, without accepted,

13 For the former see Boyer, vii. For the latter see Ian Robinson, "Zeitgeistism" (2013) at www .edgewaysbooks.com/columns/ogizeitgeistism.pdf. 
time-honoured standards and models, without the help of the wisdom of the founding fathers, was inconceivable. ${ }^{14}$

Arendt suggests that the loss of this tradition since the French Revolution is the fundamental fact of our political condition. But, as Eisenstadt puts it, "This does not mean, of course, that modern or modernizing societies are traditionless ... It means, rather, that modernization has generally weakened one specific aspect of traditionality - namely, the legitimation of social, political and cultural orders."15 This is what is behind Hobsbawm's well-known thesis about the "invention of tradition". It deals with cases where governments in the eighteenth century adopted or encouraged new traditions - usually symbolized by emblems, anthems and uniforms - in order to overcome the loss of the older traditions. Shils called Hobsbawm's thesis "frivolous" because it ignored the question of whether all traditions are invented or not. ${ }^{16}$ But we may consider Hobsbawm right to have recognized that our very consciousness of tradition is itself a sign of the loss of tradition.

The antinomy of "tradition" and "rationalism" is perhaps the precondition of the first antinomy, although it applies more to philosophy than to politics. The difference here is between the claim "Our reason for doing this is tradition" and "Our reason for doing this is something other than tradition" - because it is useful, say, or because it is right. ${ }^{17}$ If we thought, as Oakeshott did, that "rationalism" is nothing other than an abridgement of a tradition, then we would have to admit that it is a mistake to think that criticism is something which can enable us to escape from tradition. ${ }^{18}$ As Feyerabend put it in Against Method, "Rationality is not an arbiter of traditions, it is itself a tradition or an

\footnotetext{
14 Hannah Arendt, Between Past and Future: Eight Exercises in Political Thought [1st ed. 1961] (London: Penguin, 2006), 124.

15 S.N. Eisenstadt, "Post-Traditional Societies and the Continuity and Reconstruction of Tradition", in S.N. Eisenstadt (ed.) Post-Traditional Societies (New York: W.W. Norton and Co., 1972), 1-27, at 6 .

16 See Shils, A Fragment of a Sociological Autobiography, 130.

17 Collingwood's otherwise brilliant, and still ignored, account of the reasons we may offer for doing anything - out of caprice, because it is useful, because it is right, because it is a duty - may be incomplete: he ignores "because it is a tradition". See R.G. Collingwood, The New Leviathan, or Man, Society, Civilisation and Barbarism [1st ed. 1942] ed. David Boucher (Oxford: Clarendon Press, 1992), 104-24.

18 Michael Oakeshott, "Rationalism in Politics" (1949) in Michael Oakeshott, Rationalism in Politics and Other Essays, ed. Timothy Fuller (Indianapolis: Liberty Fund, 1991), 5-41.
} 
aspect of a tradition".19 If we thought, as Popper did, that "rationalism" is not the opposite of tradition but itself a "tradition", a "rationalist tradition", which itself involves the criticism of tradition, then it would be necessary to distinguish, as he does, two types of tradition: "uncritical" or "first-order" traditions on the one hand from "critical" or "second-order" traditions on the other. ${ }^{20}$ The dispute here is about whether criticism should be prior to tradition or whether tradition should be prior to criticism. These positions, as sceptics would say, are equipollent. Popper argues that "every bit, however small, of our traditional knowledge ... is open to critical examination and may be overthrown if need be". ${ }^{21}$ But Oakeshott argues that since there is no other source of our knowledge but tradition, there is no external criterion by which tradition can be judged. ${ }^{22}$ Gadamer argued that the antinomy simply had to be recognized: "I cannot accept the assertion that reason [or criticism] and authority [or tradition] are abstract antitheses, as the emancipatory enlightenment did. Rather, I assert that they stand in a basically ambivalent relation." ${ }^{23}$ In a similar manner Novalis spoke of two opposite tendencies:

on the one hand reverence for antiquity, devotion to human custom, love of the monuments of our forefathers and the glorious old state family, and joy in obedience; on the other hand the delightful feeling of freedom, the unconditional expectation of mighty spheres of influence, pleasure in the new and young, untrammelled contact with all fellow members of the state, pride in the universal validity of the human joy in

19 Paul Feyerabend, Against Method [1st ed. 1975] 4th ed. (London: Verso, 2010), 235.

$20 \quad$ Karl Popper, "Towards a Rational Theory of Tradition" (1948), in Karl Popper, Conjectures and Refutations: The Growth of Scientific Knowledge, 3rd ed. (London: Routledge and Kegan Paul, 1969), 120-35, at 122 \& 127. This article was a direct answer to Oakeshott's "Rationalism in Politics". He thought Oakeshott a "really original thinker". See the letter from Oakeshott to Popper of 27 January 1948, quoted in E. Podoksik, In Defence of Modernity: Vision and Philosophy in Michael Oakeshott (Thorverton: Imprint Academic, 2003), 177 .

21 Karl Popper, "On the So-Called Sources of Knowledge" (1979) in Karl Popper, In Search of a Better World: Lectures and Essays from Thirty Years (London: Routledge, 1992), 49.

22 "The... rationalist... may know that he owes something to others, but the rationality of his behaviour never depends on this - it depends on the judgment that what he has appropriated from others is reasonable - that is, he really begins \& ends in himself." Oakeshott to Popper, 28 January 1948. See the letter (originally from the Hoover Institution Archives) at http://www.michael-oakeshott-association.com/pdfs/mo_letters_popper.pdf.

23 Hans-Georg Gadamer, Philosophical Hermeneutics, trans. D.E. Linge (Berkeley: University of California Press, 1977), 34. 
personal rights and in the property of the whole, and a vigorous sense of citizenship. ${ }^{24}$

If we emphasize the former, then we emphasize the conditions of our experience, its conditionedness in time, its indebtedness, our debit; whereas if we emphasize the latter, then we emphasize the spirited or free element in our experience, the subjective element, its independence of conditions, which we could call our credit. What we should properly do is observe that these two tendencies are always interwoven. They are the warp and woof of our experience.

The antinomy between "tradition" and "history" is more significant to historians than philosophers or politicians. But it is the one which is most relevant to the theory I outline here: and perhaps even the most fundamental of the three. For whereas "modernity" and "rationalism" involve a dismissal of tradition, "history" involves its dissolution. Arendt comments that tradition bridges the gap between past and future. ${ }^{25}$ In contrast, history only bridges the gap between past and present. The difference is that tradition tends to assume that truth is eternal or unchanging through time, whereas the assumption of "all modern historical consciousness" is that "truth resides and reveals itself in the time-process". ${ }^{26}$ Ironically, it is this historical consciousness which has made us curious about tradition, leading to theories of tradition of the sort which have been developed by anthropologists and literary scholars and even theologians in the last few centuries. Prickett is a rare commentator who observes the irony that "few recent accounts of tradition have room for the idea that it [is] itself an evolving concept."27

In what follows I will attempt to face this difficulty. It seems to me that a theory of tradition has to be able to incorporate both contemporary theories of tradition and ancient understandings of tradition without attempting to simplify either. A tradition is what it is for the insider, the actor; but tradition is also at the same what it is for the outsider, the spectator. It is both. The three different elements of tradition which I distinguish here are related to successive determinations of the same phenomenon, with each step involving a further specification of the idea of tradition. It is fair to say that two forms of traditions did not emerge into full consciousness until the twentieth century, although they undoubtedly existed earlier than that. But the structure of the argument is not chronological but logical. The first form of tradition is what we could

\footnotetext{
24 Quoted in Prickett, Modernity, 120.

25 Arendt, Between Past and Future, 13.

26 Ibid., 68.

27 Prickett, Modernity, 14.
} 
loosely call anthropological, the second is what we could call literary, and the third is what we could call religious. But I shall not write primarily about forms of tradition (although each additional element does generate an ideal type or form of tradition): for the sake of accuracy, I shall write about the three distinctive elements found in tradition. These are continuity, canon, and core.

\section{Continuity}

The most fundamental element of tradition is continuity. All traditions have continuity. If a tradition has only continuity - and not canon or core - then it exists only in the form of present ritual. For instance, Pocock tells us that

a tradition, in its simplest form, may be thought of as an indefinite series of repetitions of an action, which on each occasion is performed on the assumption that it has been performed before, [where] each performance presupposes a previous performance, in infinite regress. ${ }^{28}$

This is a good definition. But caution is necessary here, because we should not assume that tradition is repeated action. An action is something wholly original. Shils is right to exclude it from his definition of tradition. None of the following, he tells us, is tradition: sentiment, judgment, perception, prayer, proposition, utterance, performance, and so on. ${ }^{29}$ The reason is very simple. If tradition is "anything handed down from past to present", then it excludes action, because action cannot be handed over. It "ceases to exist once it is performed". It is "the most evanescent of things". ${ }^{30}$ So it is better to say, as Oakeshott does, that an action is a "human being responding to his contingent situation by doing or saying this rather than that in relation to an imagined and wished-for outcomes and in relation, also, to some understood conditions", while a tradition is "a set of considerations, manners, uses, observances, customs, standards, canons, maxims, principles, rules and offices specifying useful procedures or denoting obligation or duties which relate to human actions and utterances". ${ }^{31}$ Traditions are not actions: they frame actions. Shils has put it

28 J.G.A. Pocock, "Time, Institutions and Action: An Essay on Traditions and their Understanding" (1968) in J.G.A. Pocock, Political Thought and History: Essays on Theory and Method (Cambridge: Cambridge University Press, 2009), 187-216, at 190.

29 Shils, Tradition, 31.

$30 \quad$ Ibid., 13.

31 Michael Oakeshott, On Human Conduct (Oxford: Clarendon Press, 1975), 32 \& 55 . 
well: "The re-enactment is not the tradition; the tradition is the pattern which guides the re-enactment."32 Or again: "Actions are not handed down; only their models, rules and legitimations are." 33

Traditions constituted only in terms of continuity do not require us to be conscious that we have a tradition. It is in relation to continuous traditions that Shils says that "those who accept a tradition need not call it a tradition." ${ }^{34}$ This is why people in "traditional societies" almost never have a concept of tradition in the sense we do in our "post-traditional societies". Oakeshott says that such a tradition

is neither fixed nor finished; it has no changeless centre to which understanding can anchor itself; there is no sovereign purpose to be perceived or invariable direction to be detected; there is no model to be copied, idea to be realized, or rule to be followed. Some parts of it change more slowly than others, but none is immune from change. Everything is temporary. ${ }^{35}$

Oakeshott thinks that such traditions are transformed by the existence of writing. For writing enables us to "abridge" our traditions so that they become what he calls "ideologies". An ideology is "a traditional manner of attending to the arrangements of a society which had been abridged into a doctrine of ends to be pursued, the abridgement being erroneously regarded as the sole guide relied upon". ${ }^{36}$ It perhaps a condition of our modernity that we exist in an imaginative world constituted by the contestation of abridgements. ${ }^{37}$

Anthropologists who study traditional societies have done the most in the last century to explore the continuous form of tradition. But many anthropologists use the word "tradition" without pondering its meaning. Boyar notes with some amusement that anthropologists often try to use the same theories to explain unchanging traditions and historical changes in the same societies. ${ }^{38}$ These problems arise, I would suggest, because anthropologists of course come from a culture with written traditions, and so are always conscious of

32 Shils, Tradition, 31 .

33 Edward Shils, "Tradition", Comparative Studies in Society and History 13 (1971): 122-159, at 127. See also Shils, Tradition, 31.

34 Shils, Tradition, 13.

35 Michael Oakeshott, "Political Education", in Oakeshott, Rationalism in Politics, 43-69, at 61.

36 Ibid., $54-5$.

37 James Alexander, 'The Major Ideologies of Liberalism, Socialism and Conservatism', Political Studies 63 (2015), 980-994.

38 Boyer, Tradition as Truth and Communication, 9 . 
traditions in a way that those in the societies they study are not. Boyer says that when one asks tribesmen in societies with no tradition of writing why they carry out certain rituals, they generally give the generic traditional answer: "That is the way we do it here". ${ }^{39}$ Traditional rituals, or what I would call continuous traditions, have three characteristics, according to Boyar. They are firstly "social", secondly "repeated", and thirdly, as he puts it, "psychologically salient", by which he means they are not merely matters of habit but of some higher significance. ${ }^{40}$ He says more than once that it is "untenable" to assume that traditions are intended to conserve some underlying conception of the world. ${ }^{41}$ And he is right, as long as it is clearly recognized that he is only concerned with continuities and not with canons or cores. An anthropologist who is more interested in the contrast between spoken and written traditions, Jack Goody, has distinguished three types of traditions depending on the source of the knowledge of how to act. There are three sources. The first is the mere activities of daily life, the second is certain heightened rituals which depend on "deep knowledge", and the third is the higher powers. ${ }^{42}$ But we cannot distinguish the second and third clearly until we have writing.

The most significant event in the history of tradition was the emergence of writing. An unwritten tradition, once it is dead, remains dead; whereas a written tradition can survive its death in some form, if its texts survive to be read again later. ${ }^{43}$ If the fundamental fact about tradition is the simple one that humans do act and think and speak in traditional manner, then the second complicating fact is that at some stage in history humans began to write. As Goody puts it, "By creating a text 'out there', a material object detached from man (who created and interprets it), the written word can become the subject of a new kind of critical attention" ${ }^{44}$ Spoken words "do not comprise a distinct category" from whatever is going on; but written words do. ${ }^{45}$ Writing fundamentally alters both religion and law, for now the memory of a community is

\footnotetext{
39 Ibid., vii.

$40 \quad$ Ibid., 1.

41 Ibid., 17, and compare 120 . He may overstate his case. On 7 he merely says the case is "rather difficult to evaluate".

42 Jack Goody, The Interface Between The Written and the Oral (Cambridge: Cambridge University Press, 1987), 156-7.

43 See Walter Ong, Orality and Literacy: The Technologizing of the Word, and ed. (London: Routledge, 2002).

44 Jack Goody, The Logic of Writing and the Organisation of Society (Cambridge: Cambridge University Press, 1986), 129 .

45 Ibid., 137.
} 
older than "the memory of the oldest living wise man". 46 Words when written are no longer acts, as they are when spoken, but works: and "such works are sacred repositories of the word of God, which in themselves remain unchanging, eternal, inspired by the divine and not by man alone". 47

But this does not mean a written tradition is solely consecratory. It can also be critical. If we wanted a good conjectural history of tradition we could say that writing was used first to defend an established tradition, then to criticize other traditions, then to criticize one's own tradition by comparing it with other traditions, then to criticize one's own tradition simply because it was traditional and not critical, and finally to criticize all and any traditions simply because they were traditional and not critical. The last of these stages is radical: involving the sort of criticism which appears not to be indebted to tradition at all. It is so conscious of the arbitrariness of tradition that in attempting to avoid arbitrariness it denies its debt to tradition altogether. And yet even this view, by the paradox noted by Popper and many others, tends to form itself into a tradition. It is easy to get caught up in circles when speaking (or, perhaps especially, when writing) about tradition.

Gadamer has written:

The full hermeneutical significance of the fact that tradition is essentially verbal becomes clear in the case of a written tradition. The detachability of language from speaking derives from the fact that it can be written. In the form of writing, all tradition is contemporaneous with each present time... No longer dependent on retelling, which mediates past knowledge with the present, understanding consciousness acquires - through its immediate access to literary tradition - a genuine opportunity to change and widen its horizon... [It] even surpasses the experience connected with the adventure of travelling and being immersed in the world of a foreign language. ${ }^{48}$

This should be clear. In a spoken tradition, there is only the moment, and the memory of the moment before that, and of the moment before that, each one evanescent; but in a written tradition, every moment can be brought into relation with an earlier moment. A literature means that the moment is no longer wholly evanescent: it gives us "contemporaneity with every present". 49

\footnotetext{
$46 \quad$ M.T. Clanchy, quoted in ibid., 164.

47 Ibid., 6.

48 Hans-Georg Gadamer, Truth and Method, 2nd ed. (New York: Continuum, 1989), 390.

49 Ibid., 391.
} 
In a continuous tradition, Goody rightly observes, "canonisation is virtually impossible". ${ }^{0}$ It is writing which enables us "to establish and validate a continuing set of beliefs in a canonized form that persists over time". ${ }^{51}$ Moments are then no longer evanescent: they leave a trace, a remain, a "fixed point of reference", which makes it possible for us to believe that in our ritual we are returning to the origin. ${ }^{52}$ Without this, there could not be canons.

\section{Canon}

By canon I mean what is distinctive in a written tradition. If a continuous tradition is one in which there is only a spoken or enacted legacy, that is, a legacy we suppose exists because there are speeches or acts which carry it over from the past, then in a tradition with a canon there also are written or literary remains which embody that legacy and apparently fix it. If anthropologists have done most to theorise the continuous element in traditions, literary critics have done most to theorise the canonical element in traditions. The classic statement about what a literary tradition is - although perhaps anticipated by Newman in his Essay on Development (1845) - is that of T.S. Eliot in his essay on tradition. ${ }^{53}$ Eliot does not say, because he takes it for granted, that his subject is not the continuous traditions associated with primitive societies. It is instead traditions which have canons. This explains why what he says appears to contradict some of what we have already heard about tradition.

According to Eliot, tradition is not concerned with "repetition". "Tradition... cannot be inherited, and if you want it you must obtain it by great labour." He supposes that the relation between the self and a tradition is not passive, but active, and involves conscious activity. It requires a historical sense - that is, we could say, a sense of the relics and remains which add to the actual, continuous, tradition what we could call the elements of virtual tradition. "This historical sense, which is a sense of the timeless as well as of the temporal and of the timeless and the temporal together, is what makes a writer traditional. And it is at the same time what makes a writer most acutely conscious of his place in

50 Jack Goody, The Power of the Written Word (Washington: Smithsonian Institution Press, 2000), 126 .

$51 \quad$ Ibid., 128.

$52 \quad$ Ibid., 122.

53 T.S. Eliot, "Tradition and the Individual Talent" (1920), in T.S. Eliot, The Sacred Wood, 7th ed. (London: Faber, 1950), 47-59. 
time, of his contemporaneity."54 Throughout his argument Eliot is concerned with the poet, the creative writer, who supposes himself to contributing to a literary canon which already exists. There is no distinction between creation and criticism - the two are the same thing. To create is to criticize; to criticize is to create: both are to adjust the established canon. So the past and present are related in the consciousness of the writer, who judges the past, while the past - in effect - judges the writer. "The two things are measured by each other." ${ }^{55}$ This is a clear statement of something not yet mentioned so far in this article - not yet mentioned because we were concerned first with solely continuous traditions, and then with a distinction between written and spoken traditions in such a way that we exaggerated the distinction between them: this is the concept of a critical canon. This is not a canon in the form of a fixed rule or measure, but in the form of a measure which itself can be measured. The following sentence, well known to students of English literature, should be better known elsewhere.

The existing order is completed before the new work arrives; for order to persist after the supervention of novelty, the whole existing order must be, if ever so slightly, altered; and so the relations, proportions, values of each work of art toward the whole are readjusted; and this is conformity between the old and the new. ${ }^{56}$

The argument is that a canon establishes standards by which we are judged, but at the same time, reflexively, as we might say, enables us by our acts to judge those standards, so that the entire canon remains continually critically open to change.

Awareness of this distinctive argument, obvious as it will be to some, brings greater exactitude into any theory of tradition. The weakness of Shils's theory was that it did not do enough to distinguish continuous traditions, in which of course there is continual adjustment of the tradition, from canonical traditions, in which there also is continual adjustment of the tradition but in a far more transparent way, since what is being adjusted remains for all to see, and remains so because it is in some sense fixed. When Oakeshott says that a tradition is "a set of considerations, manners, uses, observances, customs, standards, canons" and so on, we should note his use of the term "canons".57

\footnotetext{
$54 \quad$ Ibid., 49.

55 Ibid., 50.

$56 \quad$ Ibid., 51.

57 Oakeshott, On Human Conduct, 55 .
} 
His list includes both continuous and canonical elements (although not, we should note, core elements). This is because he is writing about written as well as spoken traditions. Such traditions, he says, lay down "conditions to be acknowledged" in action, but do not prescribe what action should be. They are, in words even Hobsbawm could approve of, "continuously invented" and are "unfinished". ${ }^{58}$ But we must insist on a distinction between continuous and canonical traditions. Traditions with canons are ones with written conditions to be acknowledged, where the continuous invention is found in the critical interaction with a set of texts.

MacIntyre observes that a tradition of this sort legitimates criticism of the tradition itself.

It is central to the conception of such a tradition that the past is never something merely to be discarded, but rather that the present is intelligible only as a commentary upon and response to the past in which the past, if necessary and if possible, is corrected and transcended, yet corrected and transcended in a way that leaves the present open to being in turn corrected and transcended by some yet more adequate future point of view. ${ }^{59}$

This is why he calls such a tradition - a canonical tradition - "an historically extended, socially embodied argument".60

In such a tradition there are "classics" or "standards", since criticism suggests that certain writings are more important or exemplary than others. The Declaration of Independence is a standard (and perhaps also a classic); The Waste Land is a classic (and perhaps also a standard). In his rather irresolute account of the nature of a "classic" Kermode repeated Eliot's suggestion that the "classic as model or criterion entails, in some form, the assumption that the ancient can be more or less immediately relevant and available, in a sense contemporaneous with the modern - or anyway that its nature is such that it can, by strategies of accommodation, be made so".61 The classic, Kermode suggested, "changes, yet retains its identity". 62 And he explained this by saying that a classic has "a surplus of signifier", by which he means that although

\footnotetext{
$58 \quad$ Ibid., 56.

59 Alasdair MacIntyre, After Virtue: A Study in Moral Theory, and ed. (London: Duckworth, 1985), 146.

6o $\quad$ Ibid., 222.

61 Frank Kermode, The Classic (London: Faber and Faber, 1975), 15-6.

62 Ibid., 80.
} 
it is subject to criticism or creative reinterpretation it always remains slightly beyond criticism, so that further criticism can be done, but which later criticism will also never completely grasp the nature of the classic. ${ }^{63}$ This is interesting, because it points to the difficulty of establishing exactly what makes a canon a canon or a classic a classic if we cannot establish what that surplus is - or if we cannot commit ourselves to believing that such a surplus is possible.

MacIntyre's later work has illustrated some of the difficulty which emerges if a literary tradition, with canons, is also a religious tradition, with a core of truth in it. In his Three Rival Versions of Moral Enquiry he distinguishes encyclopaedists, genealogists, and traditionalists, all of whom have different attitudes to the Bible. MacIntyre says that while the encyclopaedist attempts to "displace the Bible as a canonical book" in order to establish a new canon, and while the genealogist "discredit[s] the whole notion of a canon", the traditionalist seeks "to preserve and justify the canonical status of the Bible as distinct from, yet hegemonic over, all secular enquiry". ${ }^{44}$ But MacIntyre does not face very clearly the fact that a canonical tradition cannot itself legitimate such hegemony. For if a canon is subject to, and indeed in part constituted by criticism, then it does not enable us to distinguish the Bible from The Waste Land. A literary critic is of course able to consider the Bible a classic. But to consider it of canonical significance, as MacIntyre seems to do, is very different from treating it as something possessing truth, as MacIntyre also seems to do. If we refuse to speak of truth, then we are entitled to our canons, but each canon is simply justified by its existence and by whatever continuity of engagement with the canon there is in the present.

The same difficulty arises when we ask how we can justify the existence of, say, the canon of English literature. The critic most committed to this canon, F.R. Leavis, was famously not eager to theorise what he was doing. In his works Revaluation and The Great Tradition we do not find any claims about the theoretical status of criticism of the canon: instead we simply get practical criticism of the canon. ${ }^{65}$ In truth, Leavis's reticence about this was a consequence of his inclination to defend a tradition which is literary - and therefore involves judgments of value - without being religious. If there is a canon without a core, then

$63 \quad$ Ibid., 141.

64 Alasdair MacIntyre, Three Rival Versions of Moral Enquiry (London: Duckworth, 1985), 5.

65 See, for instance, the opening pages of F.R. Leavis, The Great Tradition [1st ed. 1948] (London: Pelican 1972), where one finds hardly any criteria laid down for criticism, except that a great writer "changes the possibilities of the art", and has an "awareness of the possibilities of life" (10). See also Jan Gorak, The Making of the Modern Canon: Genesis and Crisis of a Literary Idea (London: Athlone, 1991). 
judgment certainly is possible, and necessary, but final judgment is neither possible nor necessary. He summarized his critical practice in the question "This is so, is it not?" Tanner once said that Leavis's work is "importantly incomplete".66 This is right. Cowling once suggested that Leavis wanted a "substitute religion". ${ }^{67}$ This is not quite right. For Leavis believed in literature, without his literature quite being a religion: it was a substitute of a sort, but one only capable of expressing relative, changeable, truths. There is, as Kermode says, in any bit of writing a "surplus": something which gestures beyond the tradition from which it came, and cannot be explained in terms of it. ${ }^{68}$ But this surplus cannot be truth. It is something which remains subject to criticism. Hence the perpetual and constitutive irresolution of any canon of literature.

\section{Core}

The success of Eliot's argument later struck him as odd; and it is obvious after his subsequent conversion to Christianity - that he found it necessary to restate his argument so that there was not only a canon but what I call a core. 69 Indeed, it may be that his original argument is as far as someone could go who does not believe that within a tradition there is a core of unchanging truth.

The best characterization of the core of a tradition is the one in Josef Pieper's article "The Concept of Tradition".70 Much of his discussion of tradition applies to all three forms distinguished in this essay. Tradition involves, firstly, "two subjects, two personal beings, two somebodies: one who transmits and another to whom something is transmitted". It involves, secondly, a lack of reciprocity. "It is not a two-sided discussion, not a talk with each other, not a conversation. There is no back and forth, no exchange. One the contrary: one is talking, the other listening." It involves, thirdly, and obviously enough, an element of time, a "temporal sequence". For tradition does not involve contemporaries but an ancestor and a successor, a father and son, a master and a disciple, a teacher and a pupil. And it involves, finally, a distinction in rank, as the older is also superior in status, and the younger listens to him because

66 Michael Tanner, "Literature and Philosophy", The Human World, 30 (1975-76), 54-64, at 63.

67 Maurice Cowling, Religion and Public Doctrine in Modern England, Vol. 3 (Cambridge: Cambridge University Press, 2001), 572.

68 Kermode, The Classic, 51.

69 We see this in his later discussions of "orthodoxy" alongside "tradition". See T.S. Eliot After Strange Gods (London: Faber and Faber, 1934), 21.

$70 \quad$ Josef Pieper, “The Concept of Tradition", The Review of Politics 20 (1958), 465-91. 
there is some truth to be taught. ${ }^{71}$ All of this would count as a characterization of any tradition. But he himself goes beyond this, with reference not to canons - a significant omission in his argument - but to a core.

Pieper is particularly concerned with the sort of truth which is beyond criticism. He argues that if I accept a tradition on my own authority then it is no longer a tradition: or, rather, "it loses for me its character as a tradition". So even if I critically justify a tradition this means that, for me, it is no longer a tradition: for I have verified it for myself. Pieper likens accepting a tradition to believing; and says that there are two ways of annulling belief: one way is to refuse assent to it, to disbelieve; the other is to verify it for oneself. Then: "It is not received by me but appropriated, and I possess it on my own". ${ }^{72}$ Now, clearly, Pieper is here ignoring continuous or canonical traditions, in which verifying the tradition for oneself does not necessarily undermine the tradition at all. And this is because he is concerned with tradita that are beyond argument.

Tradition in an absolute sense, tradition that can never be resolved and replaced through the progress of science cannot be imagined unless it be assumed that there are tradita which by their very nature cannot be tested by experience and argument, cannot be verified. Whether there are such tradita or not - is a question that, to be sure, cannot be settled by a mere exposition of the elements making up the formal concept of tradition. ${ }^{73}$

This form of tradition is therefore distinct from the canonical form of tradition: since the idea that a tradition is something we change, increase or enrich is secondary to the necessity of conveying the truth in its original form through time. "The decisive element in the concept of tradition is that from the very first only what is received and hence was originally received, is passed on, and that nothing new is or may be added, no improvement or revision or may be made." 74 It is at this point that we come to what distinguishes a tradition with a core of truth from other traditions. It has a truth which is, in Pieper's words, a "divine utterance". ${ }^{75}$

Whoever is convinced that there is no such thing as "the word of God" or that such a thing is entirely impossible must necessarily regard all

\footnotetext{
71 Ibid., $470-71$.

72 Ibid., 473.

73 Ibid., 474 .

74 Ibid., 475 .

$75 \quad$ Ibid., 481.
} 
tradition not only as something provisional, something preliminary, or contingent, but, even more, as something ultimately non-binding. ${ }^{76}$

If we do not believe in "such a thing" as the word of God then we have only canonical or continuous traditions.

I have already noted that anthropologists have done most to study continuities, and literary critics have done most to study canons, so it should come as no surprise when I add that theologians have done most to study cores. Christianity is exemplary here. In Christianity, unlike Islam or Judaism, the word of God is not merely spoken but embodied: so it cannot be written, only written about. It is historical. Christ is the logos, the word - the "word made flesh" - but there are writings about him (the Gospels, the Epistles and so on), and there are also rituals (the Eucharist, Confession and so on). In the Bible it is written, "These things are written that ye might believe that Jesus is Christ the Son of God, and that in believing ye might have life through his name."77 If Christianity were only a canonical tradition, then a Christian would have a reflexive, historical relation to the entire tradition, much as a poet does to the tradition of poetry. There would be no such thing as repetition, only further addition. But in Christianity the core was momentary - an interruption of the world so an eternal truth could come into history - and the rituals of Christianity are imitations or repetitions or recollections of this. The writings of Christianity are not "classics": they either express or convey the word of God, or they exist only to further our understanding of the word of God.

This sort of tradition has its own problems, as indicated by the history of Christianity since the Reformation. Hooker, citing the Biblical line quoted above, observed "how much that which standeth on record hath in both those respects pre-eminence above that passeth from hand to hand." ${ }^{\text {78 }}$ In saying this, of course, he was trying, in Protestant manner, to say that the core was more important than the canon. It is perhaps a caricature to say that Protestants were those who placed core above canon, while Catholics were those one who placed canon above core. But the caricature certainly captures the disagreement when it is at its most extreme. ${ }^{79}$ The question is whether the scripture or the tradition has priority. Those who favour scripture, say the truth must have

$76 \quad$ Ibid., 481.

77 John 20.31.

78 Richard Hooker, The Laws of Ecclesiastical Polity, ed. A.S. McGrade (Cambridge: Cambridge University Press, 1989), 114.

79 For representative utterances see W.R. Inge, Protestantism (London: Thomas Nelson, 1935), 2, and J.H. Newman, An Essay on the Development of Christian Doctrine [1st ed. 1845], ed. J.M. Cameron (London: Penguin, 1974), 177. 
priority over tradition. But those who favour tradition, say that scripture itself emerged from a tradition. ${ }^{80}$ The only way to overcome the disagreement is to ground everything in faith. So we find ecumenical statements such as that of the Joint Anglican-Orthodox Doctrinal Commission of 1931, which declared: "Everything necessary for salvation can be founded on Holy Scripture as completed, explained, interpreted and understood in the Holy Tradition by the guidance of the Holy Spirit residing in the Church." 81

I do not want to venture further into Christianity, because here Christianity is only one example of a tradition with a core as well as a canon. Other theological religions, such as Judaism and Islam, which have received the word of God, also have a core; while anthropological religions like Buddhism also possess not only a canon but also a core - although, as usual, what this is is a matter of debate within the canon. It was summarized in the Four Noble Truths, but some claim that these were a later written summary of some original experience of awakening. ${ }^{82}$ As in Christianity, the core is not a mere word or truth but an event - the interruption of the word of God or of release from the cycles of rebirth (in either case, the conquest of death). If religions, theological and otherwise, are the obvious cases of traditions which possess a core as well as a canon, then at a lower level of existential necessity, we find other traditions which possess a core of truth - or possess a canon of truths which postulate the existence of an as yet unknown core of truth.

It is difficult to say whether a scientific canon possesses a core of truth in this sense. Formally, of course, in science the way something is discovered is irrelevant for its truth. The original moment has no significance. But the amount of interest we have in Darwin is an indication that, to say the least, it is hard for humans to separate the significance of a truthful discovery from the historical moment in which the discovery was made. But either way, by "truth" we clearly mean something more significant than anything Bernard Williams was interested in when he analysed "truthfulness" in terms of mere sincerity or authenticity. ${ }^{83}$ The truth, even in the abstract, is something which, to use sceptical language, is absolutely or authoritatively supposed to be the case

$80 \quad$ See C.E. Hill, Who Chose the Gospels? Probing the Great Gospel Conspiracy (Oxford: Oxford University Press, 2010).

81 Quoted in Methodias Fouyas, Orthodoxy, Roman Catholicism and Anglicanism (London: Oxford University Press, 1972), 124.

82 Geoffrey Samuel, The Origins of Yoga and Tantra: Indic Religions Until the Thirteenth Century (Cambridge: Cambridge University Press, 2009).

83 Bernard Williams, Truth and Truthfulness: An Essay in Genealogy (Princeton: Princeton University Press, 2002). For criticism see Richard Rorty, "To the Sunlit Uplands", London Review of Books, 31 October 2002, 13-15. 
about what is not evident to us. The truth is an explanation; but it is also the consequence of an intervention. In truth something "surplus" to existence, to what simply is, intervenes in what is and requires an adjustment in our attitude to what is. If $\mathrm{x} i s$, and $\mathrm{y}$ is what is true about $\mathrm{x}$, then $\mathrm{y}$ is not $\mathrm{x}$. Every tradition with a core has somewhere within it an act, an intervention, an insight, by which someone originally was "enlightened" or "awakened" or even "saved" and by the establishment of which within a tradition we too might be "enlightened" or "awakened" or "saved", even if only in a secular sense. In continuous or canonical traditions, the truth is inseparable from the flow or the sediment of the tradition - either an immediate truth (in continuous traditions) or a reflexive truth (in canonical traditions). But in a tradition with a core the tradition is not itself truth but only something attendant to truth.

Truth comes in different forms. Some traditions are founded on trivial truths; but serious traditions are founded on truths of a different order. Here the distinction between a written and spoken tradition seems fundamental: for in a written tradition the sacred origin remains in evidence. Truth is what is established in one moment of origin. This is a realisation or a revelation. Truth could then be - if we understand it in the broadest possible sense - a truth of wonder, of faith, of doubt or scepticism. ${ }^{84}$ But doubt doubts the certainty of its own truths, scepticism tends to assume or, more properly, discover that certainty cannot be established, and wonder is silent and solitary and perpetually uncertain. As Wittgenstein argued in On Certainty, it is faith which is the paradigm of all truth, even scientific truth: it is a glimpse of the timeless in time, of something which, if true, is eternally true.

Yet, in Brunner's words, "The situation is that we have this truth only when we continue to receive it afresh". ${ }^{85}$ The truth does not change; but the tradition may change and has to change. Another theologian, Congar, claimed that a religious tradition cannot be a matter of "simple conservation" but of "creative invention". ${ }^{86}$ In this he agreed with Eliot and MacIntyre. Yet the theologian has to be cautious. For the tradition is "not simply a repetition of the old" but "is an original expression, clothed in a new vocabulary; the old, belonging to eternity, is indeed repeated, but not in its former state; deployed to reply to new problems, it uses new resources drawn from a given period, fashioned by human

84 James Alexander, 'The Four Points of the Compass', Philosophy 87 (2012), 79-107.

85 Emil Brunner, Revelation and Reason: The Christian Doctrine of Faith and Knowledge, trans. Olive Wyon (London: S.C.M., 1947), 371.

86 Yves Congar, The Meaning of Tradition, trans. A.N. Woodrow (San Francisco: Ignatius Press, 1964), $114 \& 117$. 
activity". ${ }^{87}$ To repeat, the problem encountered by Christianity or any tradition with a core of truth is how to prevent the tradition from damaging the truth it was designed to preserve. The problem arises because a tradition with a core is both "the pure and simple transmission of the sacred deposit" and also "the explanation of this deposit, elaborated through its being lived, defended and explained generation after generation by the People of God".88

We may or may not believe in this sort of truth. But traditions associated with such truth clearly exist. Without this concept of tradition, a tradition understood in relation to truth, any theory of tradition would be radically incomplete. This is why Pieper insists that "a proper distinction and ordering [of tradition] is only possible if the unique status of sacred tradition is recognized and accepted." 89

\section{Conclusion}

So we have, as absolutely distinct elements of tradition:

1. the continuous element;

2. the canonical element; and

3. the core element.

These three elements enable us to distinguish three major forms of tradition. A tradition cannot be a tradition without the continuous element, but it is fundamentally altered as soon as there is a canon, and a second time as soon as there is a core. This cannot be emphasised enough: canons and cores are not essential to tradition as such, in the same way that continuity obviously is, but the arrival of each changes the nature of a tradition fundamentally. Cores and canons change traditions; but the only thing necessary is continuity. If there were no continuous element we would have only some abstracted form of action. This has no existence in the history of the world. There is no action without tradition. All traditions are therefore continuous; but many, especially now, in our age of mass literacy, are canonical; and almost every continuous tradition can be studied in such a way that we establish some sort of canon

\footnotetext{
87 Ibid., $116-7$.

88 Ibid., 125. Compare Josef Rupert Gieselmann, The Meaning of Tradition (London: Burns and Oates, 1966), 97, who writes of the "the ambivalence of tradition".

89 Josef Pieper, Tradition: Concept and Claim, trans. E. Christian Kopff (Wilmington, Delaware: ISI Books, 2008), 42.
} 
for it. Some traditions are more than this. Formally, then, there are three forms of tradition: those with only continuity, those with also a canon in addition to continuity, and those with also a core in addition to canon and continuity. In a continuous tradition, such as the tradition of repeated rituals in oral culture, the tradition is always only whatever it is in the present; in a canonical tradition, there is a consciousness of the past; and in a core tradition, there is a consciousness of something which not only transcends the past but also the present because it is of "timeless" significance - or, to put it another way, of not only human but divine significance.

In tradition, then, there may be a core, there may be a canon, and there is always some sort of continuity. The core of a tradition, if it has a core, is a proclamation, in Greek kerygma, which is divine in origin, or as if divine: something which comes from beyond us. Here I would include the Pythagorean tetractys, the Platonic ideas, the Buddhist four noble truths, the laws of logic such as law of non-contradiction, much of mathematics, possibly the laws of gravitation and thermodynamics, and, perhaps also, in the most minimal (or comical) sense, Bouvard and Pecuchet's ideés reçues, and all the other opinions or mere doxa which are elevated by us sometimes in casual utterance to eternal truths or laws. These form a core if we treat them as beyond criticism. If they are subject to criticism then they no longer constitute a core but belong to a canon. In a tradition with a core all we need to know in a strict sense is the core. The canon is simply what enables the core to be received by us. The canon of a tradition is a standard, kanón, which is immortal - in the sense that it survives many deaths - and lays down the way we judge the value of our significant activity: it is cumulative, and conscious, or conscientious, and attends to itself (by which I mean we attend to it if we want to) as a canon. Here there is no single truth to be known: so, in a sense, we need to know - impossible as it is! - the entire tradition. And because there is no truth within the tradition which serves as the criterion by which the tradition is judged - finally judged - here it is our judgment is important, which is never final judgment, or God's judgement, but merely critical judgment. This sort of tradition is continually changed, although of course within limits. Finally, the continuity of a tradition is simply the multiplicity of habits, customs, which constitute the mortal conditions of all action. Here nothing need be known except the tradition which is being received in the present. And since tradition here is everything which is not, in theory at least, momentary, then it is potentially infinite running from sacred rituals to everyday habits. A tradition of this sort can be changed as far as is possible as long as we remain convinced that the tradition has not changed beyond recognition. 
I have used the words eternal, immortal and mortal, since I think they enable us to characterize the claim involved in each concept of tradition. A tradition with a core claims that there is something of eternal significance which is in every moment; a tradition with a canon claims that there is something of immortal significance in some of what has formerly existed and that in our criticism of it continues to exist in changed form; and a tradition with only continuity claims that we simply have this tradition we happen to have, a mortal tradition. In the first case we are responsible to the core of truth, in the second case to the canon and in the third case only to whatever part of the tradition is evident to us now in our continuity.

There is a scale of moments:

firstly, the moment which is original, which we celebrate now, in our moment, because it was a moment which was eternal for all subsequent time: and replicable in moments of representation, where the boundary between real and represented is overcome (in, say, the real presence), and where the criterion for judgment is only in this original moment;

secondly, the moment which is not original, but something in itself, but nonetheless privileged: where not everything is the moment, except creation, or distinctive action, and where we need criticism or judgment in order to tell us what that significant action was, and how significant it was; and

thirdly, the moment which is always here, in us, in everything, high or low, with value or without that we say or do, without any criterion or judgment separable from the moment itself.

Much has been said about the importance of tradition. Burke spoke famously of "a partnership not only between those who are living, but between those who are living, those who are dead, and those who are to be born". ${ }^{90}$ Chesterton put this even more succinctly when he declared that tradition is "the democracy of the dead". "Tradition", he said, "refuses to submit to the small and arrogant oligarchy of those who merely happen to be walking about."11 Tradition is our tribute to the dead and the unborn if we choose to make it. There are good

9o Edmund Burke, Reflections on the Revolution in France [1st ed. 1790] (Indianapolis: Liberty Fund, 1999), 193 . 
reasons to make it. ${ }^{92}$ And I hope I have shown that this tribute has three elements and three forms.

\section{References}

Alexander, James. 2009. Shaw's Controversial Socialism Gainesville: University Press of Florida.

- 2012. 'Three Rival Views of Tradition (Arendt, Oakeshott, MacIntyre)', Journal of the Philosophy of History 6: 20-43.

- 2012. 'The Four Points of the Compass', Philosophy 87: 79-107.

2015. 'The Major Ideologies of Liberalism, Socialism and Conservatism', Political Studies 63: 980-994.

Arendt, Hannah. 2006. Between Past and Future: Eight Exercises in Political Thought. 1st ed. 1961. London: Penguin.

Boyer, Pascale. 1990. Tradition as Truth and Communication. Cambridge: Cambridge University Press.

Brunner, Emil. 1947. Revelation and Reason: The Christian Doctrine of Faith and Knowledge, trans. Olive Wyon. London: S.C.M.

Budick, Sanford. 200o. The Western Theory of Tradition: Terms and Paradigms of the Cultural Sublime. New Haven: Yale University Press.

Burke, Edmund. 1999. Reflections on the Revolution in France. 1st ed. 1790. Indianapolis: Liberty Fund.

Chesterton, G.K. 1909. Orthodoxy, 2nd ed. London: John Lane.

Clark, Stephen. 1989. "Reason, Value and Tradition" in Limits and Renewals, Vol. 1, Civil Peace and Sacred Order. Oxford: Clarendon Press, 1-26.

Collingwood, R.G. 1992. The New Leviathan, or Man, Society, Civilisation and Barbarism. 1st ed. 1942. ed. David Boucher. Oxford: Clarendon Press.

Congar, Yves. 1964. The Meaning of Tradition, trans. A.N. Woodrow. San Francisco: Ignatius Press.

Cowling, Maurice. 2001. Religion and Public Doctrine in Modern England, Vol. 3. Cambridge: Cambridge University Press.

Eisenstadt, S.N. 1972. "Post-Traditional Societies and the Continuity and Reconstruction of Tradition", in S.N. Eisenstadt (ed.) Post-Traditional Societies. New York: W.W. Norton and Co., $1-27$.

92 Clark has reminded us that "we ought to be wary of dismissing doctrines merely because we can ourselves see little or no reason to believe them, even if we hardly understand them". Stephen Clark, "Reason, Value and Tradition" in Limits and Renewals, Vol. 1, Civil Peace and Sacred Order (Oxford: Clarendon Press, 1989, 1-26, at 17. 
Eliot, T.S. 1934. After Strange Gods. London: Faber and Faber.

- 1950. "Tradition and the Individual Talent" (1920), in T.S. Eliot, The Sacred Wood, 7 th ed. London: Faber.

Feyerabend, Paul. 2010. Against Method. 1st ed. 1975. 4th ed. London: Verso.

Fouyas, Methodias. 1972. Orthodoxy, Roman Catholicism and Anglicanism. London: Oxford University Press.

Gadamer, Hans-Georg. 1977. Philosophical Hermeneutics, trans. D.E. Linge. Berkeley: University of California Press.

-1989. Truth and Method, 2nd ed. New York: Continuum.

Gieselmann, Josef Rupert. 1966. The Meaning of Tradition. London: Burns and Oates.

Goody, Jack. 1986. The Logic of Writing and the Organisation of Society. Cambridge: Cambridge University Press.

- 1987. The Interface Between The Written and the Oral. Cambridge: Cambridge University Press.

- 2000. The Power of the Written Word. Washington: Smithsonian Institution Press.

Gorak, Jan. 1991. The Making of the Modern Canon: Genesis and Crisis of a Literary Idea. London: Athlone.

Hill, C.E. 2010. Who Chose the Gospels? Probing the Great Gospel Conspiracy. Oxford: Oxford University Press.

Hooker, Richard. 1989. The Laws of Ecclesiastical Polity, ed. A.S. McGrade. Cambridge: Cambridge University Press.

Inge, W.R. 1935. Protestantism. London: Thomas Nelson.

Kermode, Frank. 1975. The Classic. London: Faber and Faber.

Leavis, F.R. 1972. The Great Tradition. 1st ed. 1948. London: Pelican.

MacIntyre, Alasdair. 1985. Three Rival Versions of Moral Enquiry. London: Duckworth.

- 1985. After Virtue: A Study in Moral Theory. 2nd ed. London: Duckworth.

Newman, J.H. 1974. An Essay on the Development of Christian Doctrine. 1st ed. 1845. ed. J.M. Cameron. London: Penguin.

Oakeshott, Michael. 1975. On Human Conduct Oxford: Clarendon Press.

- 1991. Rationalism in Politics and Other Essays, ed. Timothy Fuller. Indianapolis: Liberty Fund.

Ong, Walter. 2002. Orality and Literacy: The Technologizing of the Word, 2nd ed. London: Routledge.

Pieper, Josef. 1958. "The Concept of Tradition”, The Review of Politics 20: 465-91.

- 2008. Tradition: Concept and Claim, trans. E. Christian Kopff. Wilmington, Delaware: ISI Books.

Pocock, J.G.A. 2009. "Time, Institutions and Action: An Essay on Traditions and their Understanding" (1968) in J.G.A. Pocock, Political Thought and History: Essays on Theory and Method. Cambridge: Cambridge University Press. 
Podoksik, Efraim. 2003. In Defence of Modernity: Vision and Philosophy in Michael Oakeshott. Thorverton: Imprint Academic.

Popper, Karl. 1969. "Towards a Rational Theory of Tradition" (1948), in Karl Popper, Conjectures and Refutations: The Growth of Scientific Knowledge, 3rd ed. London: Routledge and Kegan Paul, 120-35.

- 1992. "On the So-Called Sources of Knowledge" (1979) in Karl Popper, In Search of a Better World: Lectures and Essays from Thirty Years. London: Routledge.

Prickett, Stephen. 2009. Modernity and the Reinvention of Tradition: Backing into the Future. Cambridge: Cambridge University Press.

Robinson, Ian. 2013. "Zeitgeistism" at www.edgewaysbooks.com/columns/ogizeit geistism.pdf.

Shils, Edward. 1971. "Tradition." Comparative Studies in Society and History, 13: 122-159.

-1981. Tradition. Chicago: Chicago University Press. . 2006. A Fragment of a Sociological Autobiography: The History of My Pursuit of a Few Ideas, ed. Stephen Grosby. London: Transaction.

Samuel, Geoffrey. 2009. The Origins of Yoga and Tantra: Indic Religions Until the Thirteenth Century. Cambridge: Cambridge University Press.

Rorty, Richard. 2002. "To the Sunlit Uplands", London Review of Books, 31 October, 13-15. Tanner, Michael. 1975-76. "Literature and Philosophy", The Human World, 30: 54-64. Williams, Bernard. 2002. Truth and Truthfulness: An Essay in Genealogy. Princeton: Princeton University Press. 